\title{
Edukasi Mengenai Pentingnya Ketahanan Pangan Rumah Tangga dan Model Pemanfataan Pekarangan pada Pengurus TP-PKK Desa Dame I
}

\author{
Yulianty Sanggelorang ${ }^{1 *}$, Nancy Swanida Henriette Malonda ${ }^{2}$ \\ ${ }^{1,2}$ Program Studi Ilmu Kesehatan Masyarakat, Fakultas Kesehatan Masyarakat, \\ Universitas Sam Ratulangi Manado, 95115, Sulawesi Utara, Indonesia \\ *Penulis korespondensi. Email: y.sanggelorang@unsrat.ac.id
}

\begin{abstract}
ABSTRAK
Status gizi setiap individu secara tidak langsung dipengaruhi oleh ketahanan pangan rumah tangga. Kejadian kurang gizi kronis lebih berisiko terjadi pada anak dari keluarga rawan pangan dibandingkan yang tahan pangan. Peningkatan pengetahuan demi mendukung perubahan perilaku dalam hal ini pemanfataan pekarangan guna mendukung ketahanan pangan. Tujuan kegiatan ini yaitu meningkatkan pengetahuan anggota TP-PKK Desa Dame I tentang pentingnya ketahanan pangan rumah tangga guna mencegah terjadinya kurang gizi kronis serta menginisiasi model pemanfaatan pekarangan. Metode pelaksanaan kegiatan melalui penyuluhan dan diskusi serta pengukuran tingkat pengetahuan menggunakan kuesioner (pre-test dan post-test). Hasil pengukuran menunjukan peningkatan pengetahuan dengan peningkatan proporsi peserta yang kategori pengetahuannya baik. Usulan model pemanfataan pekarangan melalui Kawasan Rumah Pangan Lestari (KRPL) di setiap lindongan juga mendapat respon baik dari mitra. Sehingga dapat disumpulkan bahwa kegiatan penyuluhan berhasil dengan baik dan lewat peningkatan pengetahuan ini peserta diharapkan dapat mengaplikasikan teori melalui pemanfaatan pekarangan di setiap lindongan.
\end{abstract}

Kata Kunci: ketahanan pangan rumah tangga, gizi kurang, pemanfaatan pekarangan

\begin{abstract}
ABTRACT
Household food security is indirectly affected the nutritional status. Chronic undernutrition is more at risk for children from food insecure families than those who are food secure. Increased knowledge to support behavior change, in this case the use of backyards to support household food security. The purpose of this program was to increase the knowledge of TP-PKK Dame I members about the importance of household food security in order to prevent chronic malnutrition and to initiate the backyard utilization model. The method of implementing activities was through counseling and discussion and measuring the level of knowledge using a questionnaire (pre-test and post-test). The measurement results showed an increase in knowledge with an increase in the proportion of participants with good knowledge categories. The proposed model for using backyards through the Kawasan Rumah Pangan Lestari (KRPL) in each lindongan also received a good response from the partners. So that it can be concluded that this program was working well and through this increase in knowledge the participants are expected to be able to apply the theory through the use of backyards in each lindongan.
\end{abstract}

Keyword: household food security, under nutrition, backyard 
menjadi kelompok kunci dalam menjamin ketahanan pangan tingkat rumah tangga sebagai salah satu upaya dini pencegahan dan penanggulangan masalah gizi kronis.

Ketahanan pangan rumah tangga sebagai salah satu penyebab kejadian gizi kronis, merupakan permasalahan yang telah lama dihadapi dan semakin berat dengan kondisi pandemi yang terjadi tahun 2020 ini. Pandemi Corona Virus Disease (COVID-19) berdampak pada semua aspek kehidupan, ketahanan pangan salah satunya. Schmidhuber et al. (2020) dalam analisisnya menyatakan bahwa pandemi COVID-19 ini berpengaruh pada sektor pangan dan pertanian melalui berbagai mekanisme, mulai dari gangguan perdagangan internasional hingga penurunan produksi dalam negeri dan penurunan daya beli masyarakat. Kondisi ini menjadi tantangan yang besar terhadap ketahanan pangan rumah tangga.

Permasalahan ketahanan pangan rumah tangga dapat diatasi salah satunya dengan pemanfataan pekarangan (Ashari et al., 2016). Namun berdasarkan data dari Badan Ketahanan Pangan untuk di Kabupaten Sitaro belum ada Kawasan Rumah Pangan Lestari (BKP Kementan, 2019). Namun, Kawasan Rumah Pangan Lestari (KRPL) merupakan salah satu model pemanfataan pekarangan sebagai upaya menjamin ketahanan pangan rumah tangga. Hasil kegiatan Program Kemitraan Masyarakat tahun 2019 pada Wanita Kaum Ibu (WKI) di Jemaat GMIST Immanuel Dame yang berlokasi di Kabupaten Sitaro menunjukan bahwa sudah terjadi peningkatan pengetahuan mengenai ketahanan pangan rumah tangga (Sanggelorang \& Rahman, 2019). Namun, hal ini belum diiringi dengan perubahan perilaku terutama dalam hal pemanfataan pekarangan.

Program kemitraan masyarakat TP-PKK Desa Dame I yang rencananya akan dilaksanakan tahun 2020 bertujuan untuk mengatasi permasalahan ini. Rencana kegiatan yang paling mendasar adalah dengan meningkatkan pengetahuan anggota TP-PKK Desa Dame I, yang diharapkan dengan adanya peningkatan pengetahuan ini akan terjadi perubahan perilaku. Perubahan perilaku ini tercermin salah satunya dengan bertambahnya rumah tangga yang memanfaatkan pekarangannya guna menanam bahan pangan (dapur hidup) juga tanaman obat (toko obat keluarga). bertanggungjawab terhadap penyelenggaraan 
d. Pemanfaatan pekarangan sebagai salah satu solusi mencegah kerawanan pangan

e. Model pemanfaatan pekarangan untuk diterapkan di Desa Dame I rumah tangga demi menjamin kualitas kesehatan anggota rumah tangga dan menginisiasi model pemanfaatan pekarangan.

\section{Tujuan dan Manfaat Kegiatan}

Kegiatan pengabdian lewat penyuluhan ini bertujuan meningkatkan pengetahuan anggota TP-PKK Desa Dame I tentang pentingnya ketahanan pangan rumah tangga guna mencegah terjadinya kurang gizi pada seluruh anggota rumah tangga serta menginisiasi model pemanfaatan pekarangan.

\section{METODE PELAKSANAAN}

\section{Sasaran Kegiatan Pengabdian}

Mitra pada kegiatan ini adalah Ibu Rumah Tangga yang tergabung sebagai Pengurus TPPKK Desa Dame I Kecamatan Siau Timur Kabupaten Sitaro. Status sebagai ibu rumah tangga dan pengurus TP-PKK pada umumnya bertanggungjawab sebagai penyelenggara makan keluarga memungkinkan dilakukan kegiatan penyuluhan terkait ketahanan pangan keluarga agar kelompok kunci ini dapat menerapkan kiat dan solusi yang ditawarkan guna menjamin ketahanan pangan keluarga masing-masing. Tugas sebagai pengurus TP-PKK memungkinkan mendukung kegiatan ini karena dapat langsung dilaksanakan sesuai dengan program kerja mereka.

\section{Lokasi Kegiatan Pengabdian}

Kegiatan dilakukan di Balai Desa Dame I, Kecamatan Siau Timur, Kabupaten Kepulauan Siau Tagulandang Biaro.

\section{Metode yang Digunakan}

Metode yang digunakan dalam kegiatan ini yaitu penyuluhan dan diskusi terutama terkait model pemanfaatan pekarangan yang diusulkan, juga ada pembagian brosur (melalui pesan singkat menggunakan media whatsapp) yang kontennya sama dengan konten materi penyuluhan. Materi mengenai ketahanan pangan rumah tangga dibahas dengan topik-topik sebagai berikut:

a. Pengertian ketahanan pangan rumah tangga

b. Pemetaan kerawanan pangan di Sulawesi Utara

c. Hubungan ketahanan pangan rumah tangga dengan gizi kurang kronis pada anak

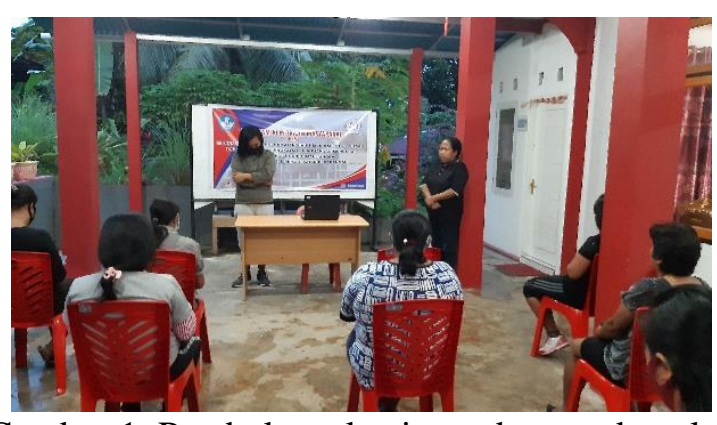

Gambar 1. Pembukaan kegiatan dengan doa oleh salah seorang Pengurus TP-PKK Desa Dame I

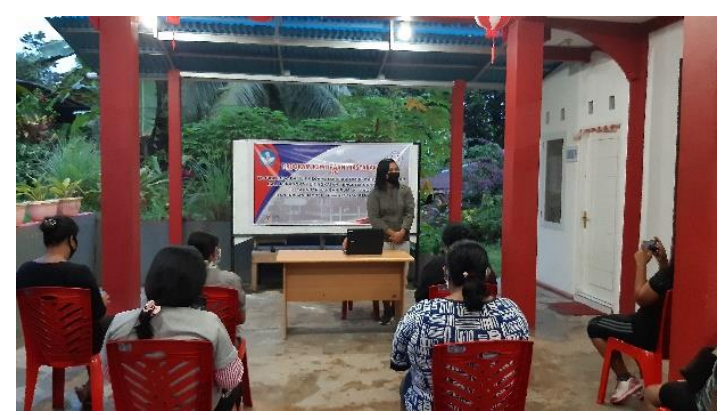

Gambar 2. Kegiatan penyuluhan dan diskusi bersama peserta

Penyuluhan diakhir dengan sesi tanya jawab. Guna menilai tingkat pengetahuan, peserta kegiatan mengisi kuesioner di awal (pretest) kegiatan penyuluhan kemudian kuesioner yang sama diisi kembali pada akhir kegiatan (posttest).

\section{HASIL DAN PEMBAHASAN}

Peningkatan pengetahuan mengenai ketahanan pangan rumah tangga pada Pengurus TP-PKK Desa Dame I melalui kegiatan penyuluhan serta inisiasi model pemanfaatan pekarangan telah terlaksana pada tanggal 10 Oktober 2020 Pukul 16.00 - 18.00 WITA bertempat di Balai Desa Dame I yang diikuti oleh 12 orang Pengurus TP-PKK Desa Dame I dan melibatkan 2 orang mahasiswa.

Kegiatan penyuluhan yang diharapkan dapat meningkatkan tingkat pengetahuan peserta kegiatan mengenai ketahanan pangan kemudian diukur dengan instrumen kuesioner pengetahuan yang diisi sebelum dan setelah penyuluhan dilaksanakan. Gambaran pengetahuan peserta kegiatan dapat dilihat dalam grafik berikut. 
kemudian akan dibahas dalam rapat bersama seluruh anggota TP-PKK Desa Dame I. Penerapan konsep Kawasan Rumah Pangan Lestari dapat menjadi awal yang baik untuk kemudian diadaptasi di setiap rumah tangga dengan memanfaatkan pekarangan guna menanam bahan pangan demi mencukupi kebutuhan keluarga dan secara tidak langsung dapat membantu perekonomian. Pemanfaatan pekarangan ini sejalan dengan program Kementerian Pertanian dalam menyediakan pangan lokal melalui Pekarangan Pangan Lestari.

Menurut laporan International Food Policy Research Institute (IPRI) pandemi COVID-19 memunculkan krisis pangan baru yang berefek pada ketahanan pangan. Laporan terbaru lainnya dari World Food Programme dan SMERU Research Institute menyatakan bahwa di Indonesia kondisi pandemi ini berpengaruh dalam hal pasokan pangan (Arif et al., 2020; IFPRI, 2020). Sehingga, sangat baik jika setiap rumah tangga dapat memanfaatkan pekarangan guna bercocok tanam bahan pangan dalam masa pandemi ini guna mendukung ketahanan pangan rumah tangga, mengingat kondisi Kabupaten Sitaro yang tergolong rawan pangan secara ekologi karena akses ke setiap pulau bergantung pada kondisi cuaca.

\section{KESIMPULAN DAN SARAN \\ Kesimpulan}

1. Penyuluhan tentang ketahanan pangan rumah tangga dapat meningkatkan pengetahuan mitra mengenai pentingnya ketahanan pangan rumah tangga.

2. Model pemanfataan pekarangan yang diusulkan yaitu membuat serupa dengan konsep Kawasan Rumah Pangan Lestari di setiap lindongan mendapatkan respon baik dari mitra.

\section{Saran}

Perlu diadakan kegiatan penyuluhan yang berkelanjutan pada kelompok masyarakat, terutama untuk daerah yang rawan pangan agar bisa mendorong terjadinya perubahan perilaku, serta bagi masyarakat agar lebih memanfaatkan lahan yang ada secara optimal demi mendukung ketahanan pangan rumah tangga.

\section{UCAPAN TERIMA KASIH}

Terima kasih kepada Lembaga Penelitian dan Pengabdian Masyarakat Universitas Sam usulan dan menyatakan ketertarikannya untuk 
(eds.); I). Penebar Swadaya.

Ratulangi (LPPM Unsrat) yang telah mendanai kegiatan Program Kemitraan Masyarakat tahun pendanaan 2019. Terima kasih kepada ketua dan semua pengurus TP-PKK Desa Dame I atas kerjasamanya sebagai mitra dalam kegiatan ini dan membantu pelaksanaannya.

\section{DAFTAR PUSTAKA}

Adriani, M., \& Wirjatmadi, B. (2012). Peranan Gizi Dalam Siklus Kehidupan (I). Kencana Prenada Media Group.

AntaraNews. (2020). Dinas Pangan dan Pertanian Sitaro Ajak Masyarakat Gemar Menanam. Terbaiknews.Net. https://terbaiknews.net/location/sulawesiutara/dinas-pangan-dan-pertanian-sitaroajak-masyarakat-gemar-menanam4131912.html

Arif, S., Isdijoso, W., Fatah, A. R., \& Tamyis, A. R. (2020). Tinjauan Strategis Ketahanan Pangan dan Gizi di Indonesia.

Ashari, N., Saptana, N., \& Purwantini, T. B. (2016). Potensi dan Prospek Pemanfaatan Lahan Pekarangan untuk Mendukung Ketahanan Pangan. Forum Penelitian Agro Ekonomi, $\quad 30(1), \quad 13$ https://doi.org/10.21082/fae.v30n1.2012.13 $-30$

BKP Kementan. (2018). Peta Ketahanan dan Kerentanan Pangan Indonesia (A Food Security and Vulnerability Atlas of Indonesia).

BKP Kementan. (2019). Kawasan Rumah Pangan Lestari. Data Kabupaten KRPL.

IFPRI. (2020). COVID-19 \& global food security.

Khomsan, A., Setiawan, B., Kusharto, C., Pranadji, D., Karsin, E., Anwar, F., Riyadi, H., Hardiansyah, Roosita, K., Yuliati, L., Rimbawan, Retnaningsih, Madanijah, S., Sibarani, S., \& Baliwati, Y. (2004). Pengantar Pangan dan Gizi (Y. F. Baliwati, A. Khomsan, \& M. Dwiriani
Masrin, Paratmanitya, Y., \& Aprilia, V. (2014). Household food security correlated with stunting in children 6-23 months. Jurnal Gizi Dan Dietetik Indonesia (Indonesian Journal of Nutrition and Dietetics), 2(3), 103-115.

https://doi.org/10.21927/ijnd.2014.2(3).103 $-115$

Undang-Undang Nomor 18 Tahun 2012 Tentang Pangan, (2012).

Sanggelorang, Y., Farmawati, A., \& Sudargo, T. (2017). Ketahanan Pangan Rumah Tangga Sebagai Faktor Risiko Kejadian Stunting Pada Anak Usia 3-5 Tahun Di Daerah Pesisir Kecamatan Siau Timur Kabupaten Sitaro [Universitas Gadjah Mada]. http://libmed.ugm.ac.id/showDetail.php?co l=kyi\&id=19846

Sanggelorang, Y., \& Rahman, A. (2019). Penyuluhan Mengenai Ketahanan Pangan Rumah Tangga Sebagai Upaya Pencegahan Masalah Gizi Kronis ( Stunting ) di Wanita Kaum. Vivabio: Jurnal Pengabdian Multidisiplin, $\quad 1, \quad 8-12$. https://ejournal.unsrat.ac.id/index.php/viva bio/article/view/25443/25100

Schmidhuber, J., Pound, J., \& Qiao, B. (2020). COVID-19: Channels of transmission to food and agriculture. Food and Agriculture Organization of the United Nation. http://www.fao.org/3/ca8430en/CA8430E N.pdf

WHO. (2014). WHA Global Nutrition Targets 2025: Stunting Policy Brief. https://doi.org/10.1016/j.ehb.2005.05.005

Yusuf, A. (2018). OPTIMALISASI LAHAN PEKARANGAN UNTUK MENDUKUNG KETAHANAN PANGAN DAN EKONOMI KELUARGA. Jurnal Pengabdian Kepada Masyarakat, 2(2), 104-108. http://jurnal.unpad.ac.id/pkm/article/view/1 6554 